Republic on the Wire 



\section{Republic on the Wire}

Cable Television, Pluralism, and the Politics of New Technologies, 1948-1984

JOHN MCMURRIA

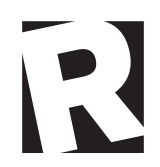

RUTGERS UNIVERSITY PRESS 
Library of Congress Cataloging-in-Publication Data

Names: McMurria, John, 1963-author.

Title: Republic on the wire : cable television, pluralism, and the

politics of new technologies, 1948-1984 / John McMurria.

Description: New Brunswick, New Jersey : Rutgers University Press, 2017. |

Includes bibliographical references and index.

Identifiers: LCCN 2016015543| ISBN 9780813585307 (hardback) |

ISBN 9780813585291 (pbk.) | ISBN 9780813585314 (e-book (epub)) |

ISBN 9780813585321 (e-book (Web PDF))

Subjects: LCSH: Cable television-United States-History. |

Broadcasting-United States-History. | Television broadcasting-United States-

History. | BISAC: SOCIAL SCIENCE / Media Studies. | TECHNOLOGY \& ENGINEERING /

Telecommunications. | HISTORY / United States / 20th Century.

Classification: LCC HE8700.72.U6 M46 2017 | DDC 384.55/50973-dc23

LC record available at https://lccn.loc.gov/2016015543

A British Cataloging-in-Publication record for this book is available from the British Library.

Copyright ( 2017 by John McMurria

All rights reserved

No part of this book may be reproduced or utilized in any form or by any means, electronic or mechanical, or by any information storage and retrieval system, without written permission from the publisher. Please contact Rutgers University Press, 106 Somerset Street, New Brunswick, NJ 08901. The only exception to this prohibition is "fair use" as defined by U.S. copyright law.

www.rutgersuniversitypress.org

Manufactured in the United States of America 
For my mother, Marion, Lytle, Miller, Lori, Fergus, and Doug and

In loving memory of my father, my sister Ann, and my brother David 
